\title{
ANATOMICAL CHANGES IN NORMAL SACRO-ILIAC JOINTS DURING CHILDHOOD AND COMPARISON WITH THE CHANGES IN STILL'S DISEASE*
}

\author{
BY \\ MARY E. CARTER AND G. LOEWI \\ From the M.R.C. Rheumatism Research Unit, Canadian Red Cross Memorial Hospital, Taplow, Berks
}

In the preceding paper (Carter, 1962) the incidence and clinical associations of radiological sacro-iliitis in Still's disease are described. Since the interpretation of these radiological changes in juveniles is difficult, we have correlated them with the anatomical structure of juvenile joints using pelves obtained post mortem from nine patients of varying ages without joint disease, together with two specimens from patients suffering from juvenile rheumatoid arthritis.

\section{Method}

Part of the pelvis was removed post mortem by sawing through the spine at the level of L3, and through the two ilia about 3 in. lateral to the sacro-iliac joints, thus allowing the removal of the whole sacrum, sacro-iliac oints, and part of the ilia.

These specimens were placed in clamps on the $x$-ray table corresponding to the normal supine position in vivo, and antero-posterior films were taken. They were then tomographed in a series of $1-\mathrm{cm}$. cuts starting anteriorly. After fixing in formol-saline and freezing in a solid $\mathrm{CO}_{2}$-ethanol mixture, the sacrum was sawn sagittally through the centre. Each sacro-iliac joint was then cut into coronal slices from the anterior to the posterior surface in thicknesses of $1 \mathrm{~cm}$. to correspond approximately with the tomograph cuts; these slices were $x$-rayed and photographed.

The joint slices were decalcified, and selected portions of joint were double-embedded in celloidin and paraffin wax (Peterfi's method). Sections were cut at $5 \mu$ and stained with haematoxylin and eosin.

\section{Material}

Nine pelves were obtained for comparison with those of the two patients with Still's disease, of the following ages: stillborn, $2 \frac{1}{2}$ years, $3 \frac{1}{2}$ years, 7 years, 9 years (Still's disease), 12 years, 17 years (two), 18 years, 20 years (Still's disease), and 21 years.

With the exception of the two cases of Still's disease, none of these subjects had suffered from chronic joint disease.

* This article is based on a thesis submitted for the degree of Doctor of Medicine of the University of London, since when additional material has been collected with the collaboration of Dr. G. Loewi.

\section{Macroscopic and Microscopic Appearances of Coronal Sections of Normal Sacro-iliac Joints}

All joints show a narrow space, which is slightly wider in the lower and most anterior parts of the joint, compared with the upper and more posterior parts of the joint. The cartilage is glistening and bluish-white on the sacral side of all joints and is thicker than on the iliac side, which is duller and rougher. The sacral cartilage averages approximately $4 \mathrm{~mm}$. in thickness and may be as much as $6 \mathrm{~mm}$. in the anterior part of the joint, though towards the posterior and upper parts it narrows to $1 \mathrm{~mm}$. or less. The iliac cartilage does not exceed $2 \mathrm{~mm}$. in thickness and is frequently only a membrane-like layer covering the bony surface. The cartilage on both sides of the joint merges into fibrous tissue at the upper part of all but the most anterior slices, until, in the most posterior sections, there is little or no cartilage or space left.

Microscopically, there is little change in the sacral articular cartilage at different ages, the cells being fairly uniformly distributed throughout the matrix and the joint surface being smooth, although in the older specimens some splitting is seen, though much less marked than in the iliac cartilage. There is considerable difference between the iliac cartilage of the newborn (which resembles the sacral cartilage) and that in the older specimens. In the latter, the chondrocytes are arranged in clusters and in rows at right-angles to the joint surface, with condensation of matrix around them, and there is tangential flaking and splitting of the cartilage in a mainly radial direction. These changes increase considerably with age.

Case 1, male (new-born).-The articular cartilage in this specimen shows no special orientation of chondrocytes, and the sacral and iliac cartilage are similar, both smooth-edged and intact at the surface. Fig. $1 a-d$, (overleaf) shows the macroscopic and microscopic appearances of the left sacro-iliac joint.

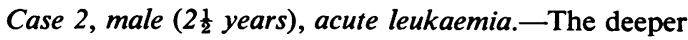


Fig. 1(a) - Case 1 (newborn). Second slice of left sacro-iliac joint.

Fig. 1(b).--Lower end of left sacro-iliac joint. Sacral cartilage on left and iliac on right. $\quad \times 12$.

Fig. 1(c).-Section of sacral cartilage and joint margin. $\times 130$.

Fig. 1(d).-Section of iliac cartilage and joint margin. $\times 130$. 
iliac cartilage in these joints shows an arrangement of chondrocyte clusters in rows more or less at right-angles to the joint surface. These cells are surrounded by a condensed matrix, which is not apparent in the sacral cartilage where the cells are more uniformly distributed.
The sacral margin is smooth and intact, whereas there are small splits in the iliac cartilage. Fig. 2(a-g) illustrates the macroscopic and radiological appearances of these joints. Fig $2 h-j$ (overleaf) shows the microscopic appearances.

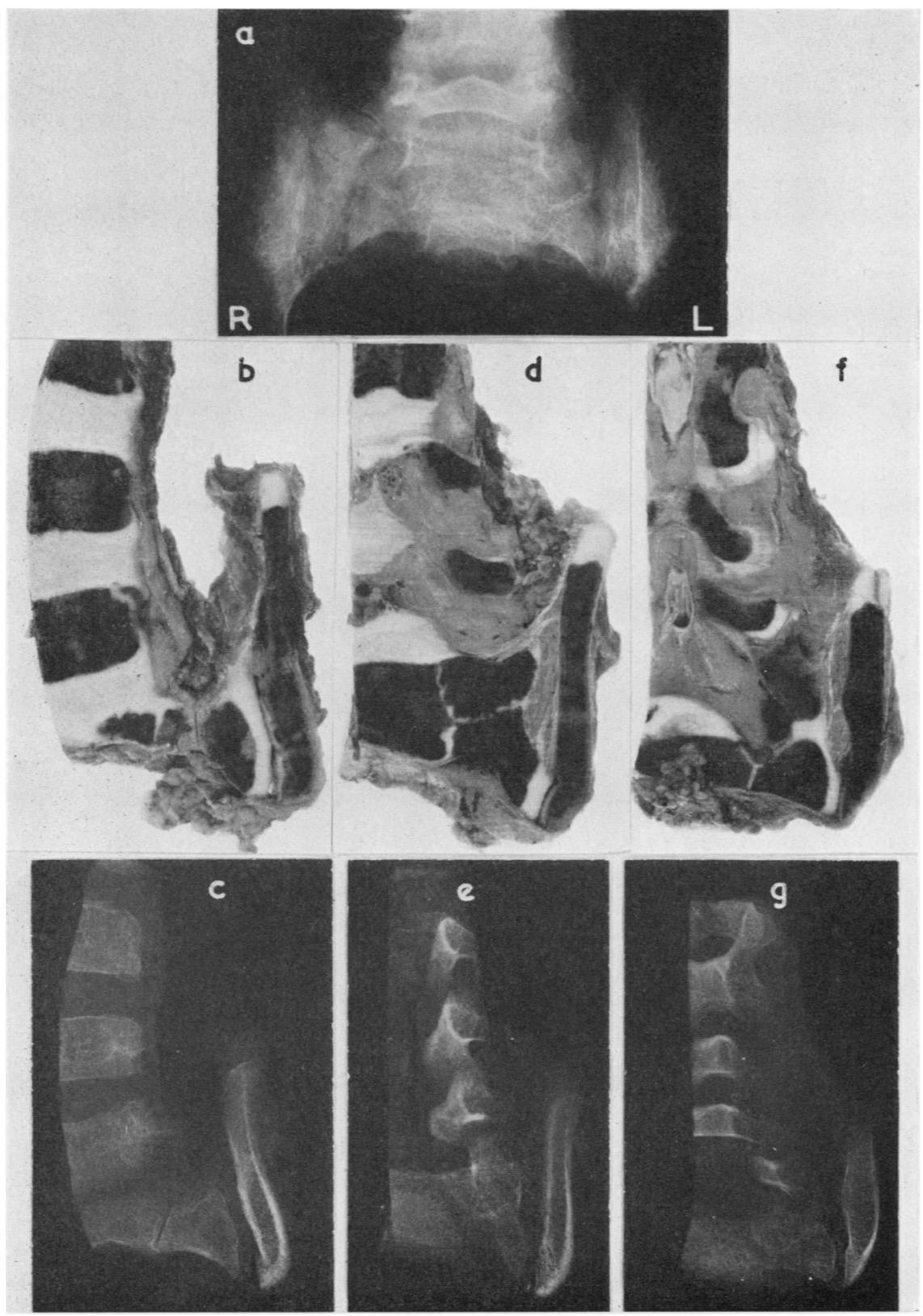

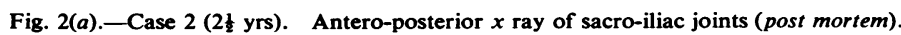

Fig. 2(b).-Slice 1 (anterior) of left sacro-iliac joint. Fig. 2(d). -Slice 2 of left sacro-iliac joint. Fig. 2(f).-Slice 3 (posterior) of left sacro-iliac joint. 
Fig. 2(h).-Lower end of left sacro-iliac joint (Slice 1). Sacral cartilage on left, iliac on right. $\quad \times 12$. Fig. 2(i).-Section of sacral cartilage and joint margin. $\times 130$

Fig. 2(j).-Section of iliac cartilage and joint margin. $\times 130$. 
Case 3, male (7 years), ventricular septal defect.-This specimen shows joints lined with sacral and iliac cartilage with smooth surfaces and is similar microscopically to the preceding case. Fig. 3(a-c) shows a slice of the left joint and its corresponding $x$ ray and the microscopic appearance of the joint.

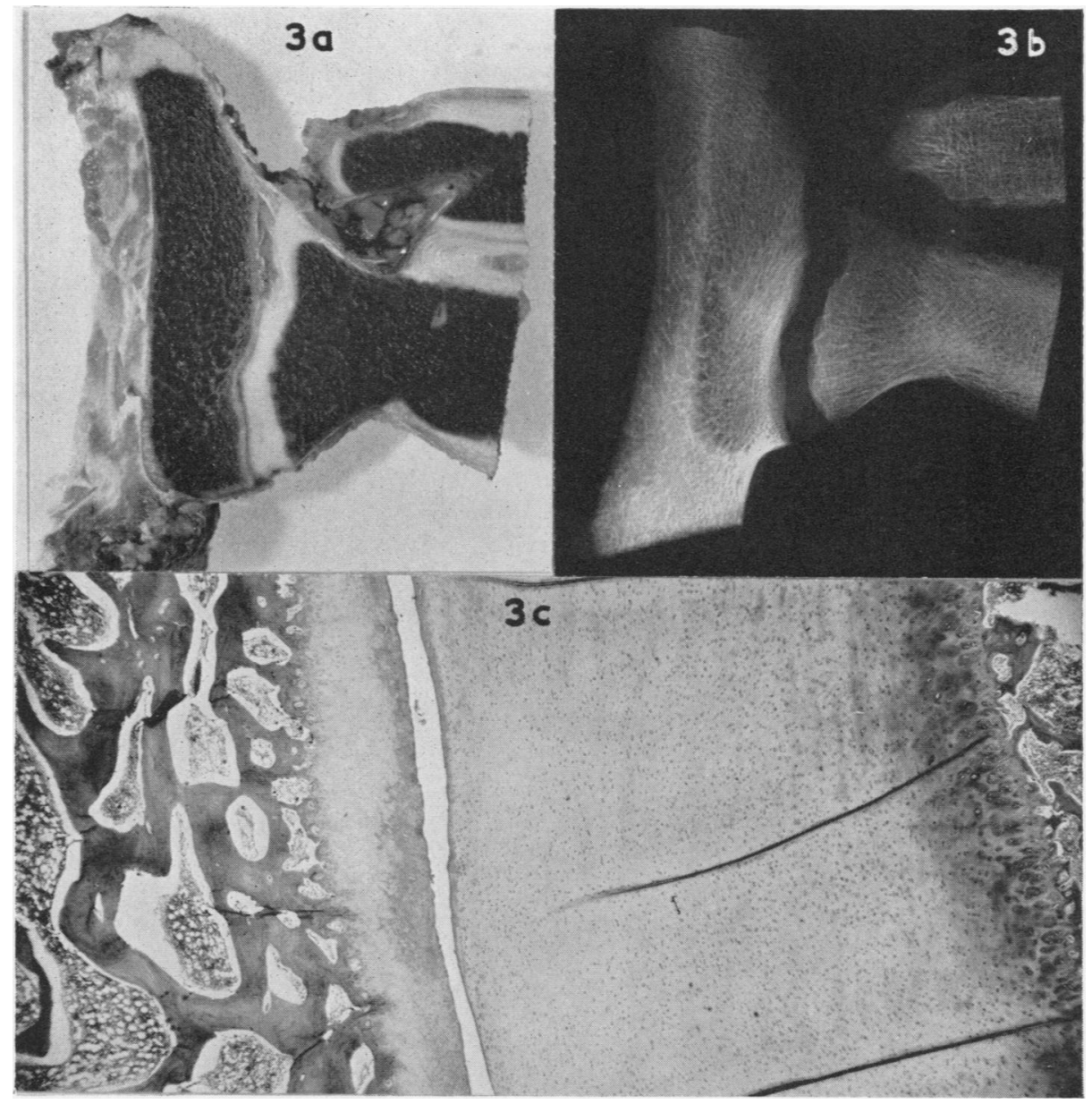

Fig. 3(a).-Case 3 (7 yrs). Slice 1 (anterior) of left sacro-iliac joint.

Fig. 3(b).-Radiograph of Slice 1.

Fig. 3(c).-Lower end of left sacro-iliac joint. Sacral cartilage on right and iliac on left. $\times 14$.

Case 4, female (12 years), juvenile cirrhosis.-The left sacro-iliac joint was cut into four slices. The most anterior slice shows a narrow space throughout the length of the section bordered by the smooth, thick sacral cartilage and narrower, duller iliac cartilage. Microscopic examination reveals irregular splitting of 
the iliac cartilage, around and between the large chondrocyte clusters. This change is greater than that seen in the other "normal" cases. Slice 2 shows narrower cartilage, but there is still a hair-line of joint space throughout the section. Slice 3 shows joint space in the lower third only, and the cartilage in the upper twothirds is replaced by fibrous tissue connecting the sacral and iliac bone. The most posterior slice shows a thinner band of sacral cartilage and a membrane-thin layer of iliac cartilage, and the joint space now completely $\overrightarrow{\vec{\omega}}$ obliterated by fibrous tissue.

Fig. $4(a-i)$ and $(j-l)$ (opposite) illustrate the anteroposterior pelvic $x$ ray, four joint slices with corresponding $x$ rays, and the microscopic appearance of Slice 1 .

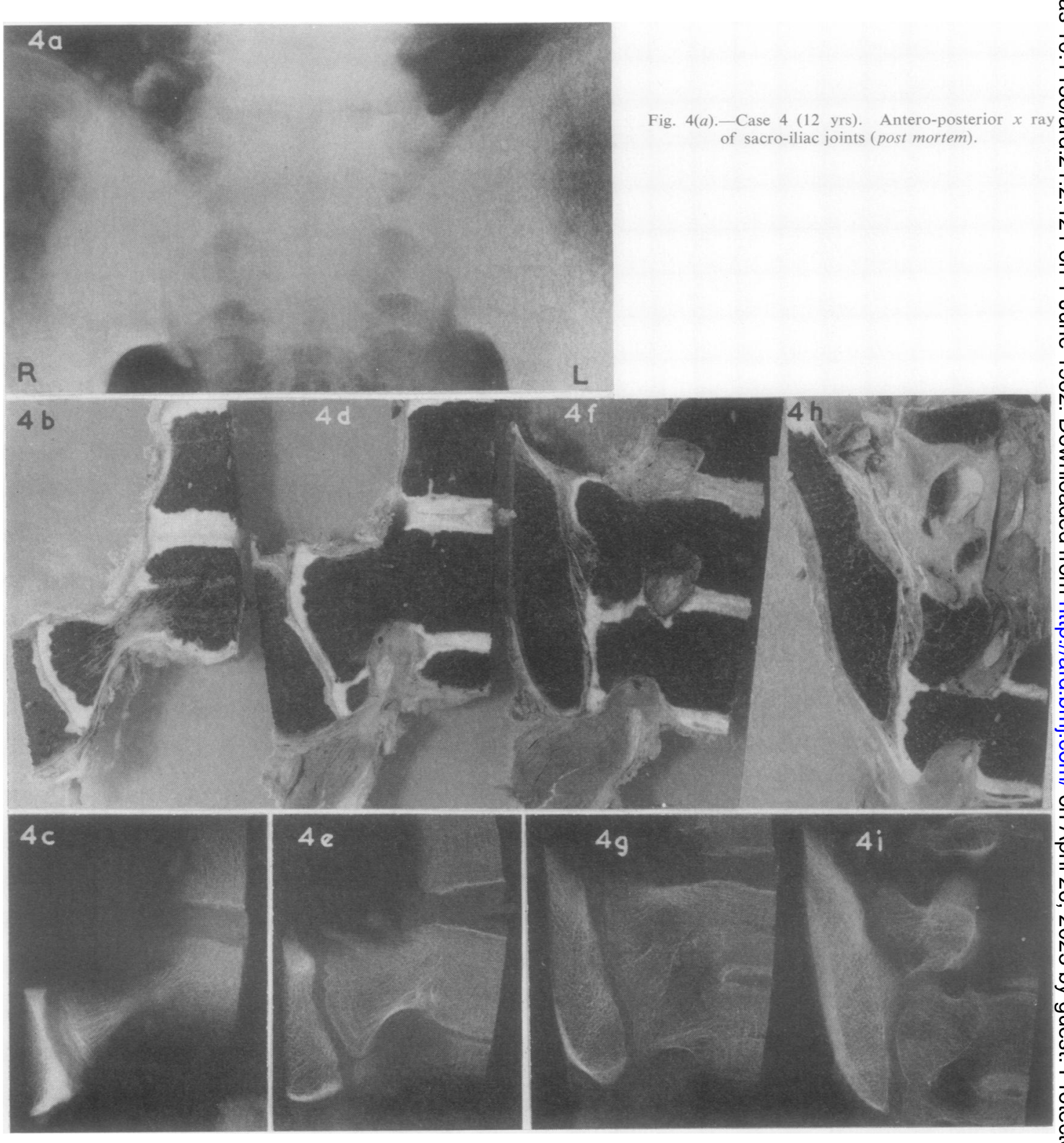

Fig. 4(b).-Slice 1 (anterior) of left Fig. $4(d)$.- Slice 2 of left sacro- Fig. $4(f)$.-Slice 3 of left sacro- Fig. $4(h)$.-Slice 4 of left sacrosacro-iliac joint.

Fig. 4(c).--Radiograph of Slice 1.

Fig. 4(e).-Radiograph of Slice 2.

Fig. $4(\mathrm{~g})$.- Radiograph of Slice 3. Fig. $4(\mathrm{i})$.- - Radiograph of Slice 4 .

Fig. $4(\mathrm{~g})$.- Radiograph of Slice 3. Fig. $4(\mathrm{i})$.- - Radiograph of Slice 4 . 

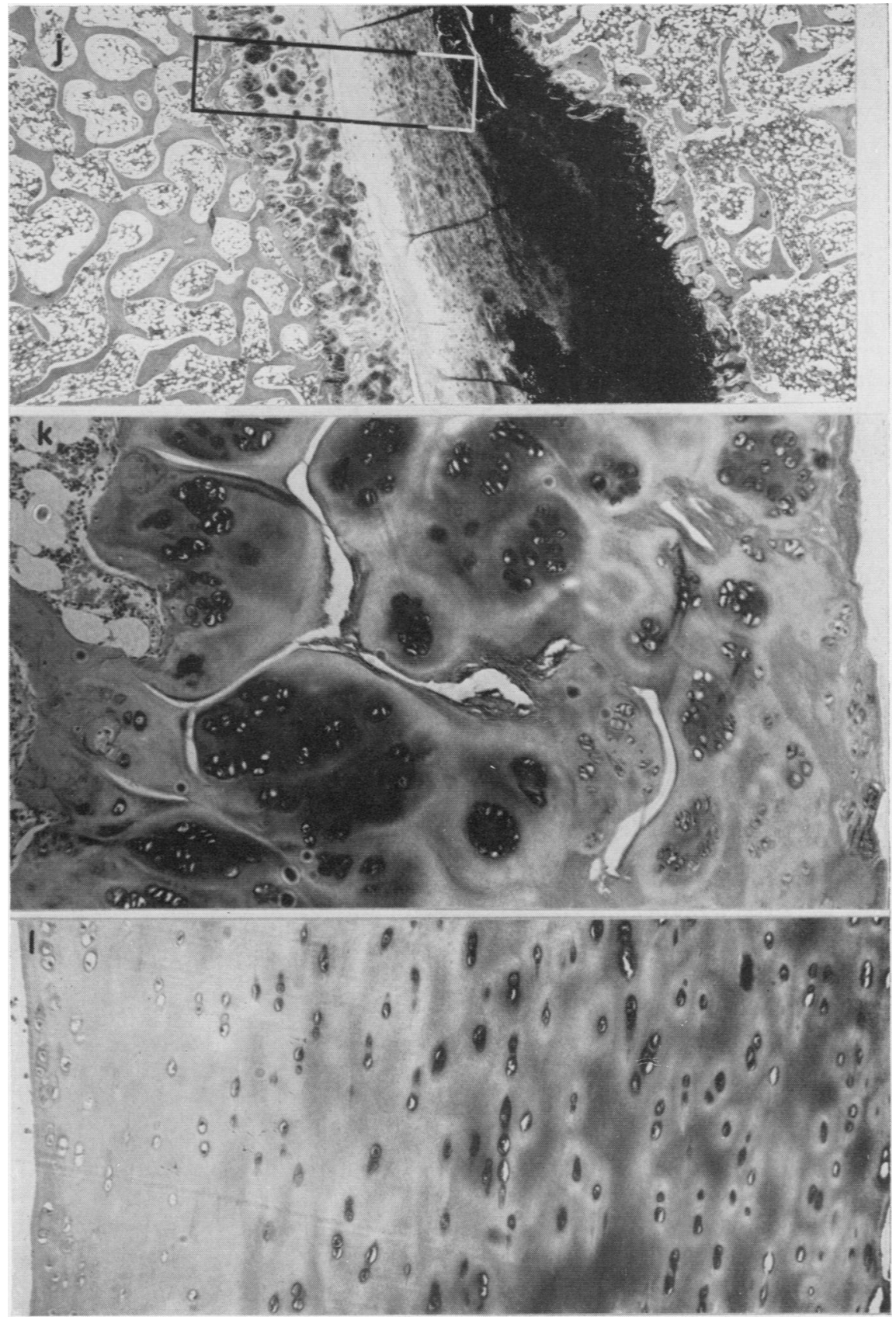

Fig. $4(j)$.-Mid-zone of left sacro-iliac joint at level of Slice 1. Sacral cartilage on right and iliac cartilage on left. $\times 12$ Fig. $4(k)$.- Section of iliac cartilage and joint margin. $\times 105$.

Fig. 4(l).-Section of sacral cartilage and joint margin. $\times 105$. 
Cases 5 and 6, males (17 and 21 years), acute leukaemia and acute glomerular nephritis respectively.-These specimens exhibit the same features as the younger joints, with broad, smooth sacral cartilage and narrower, irregular iliac cartilage, but in these older specimens the iliac cartilage surface shows more splits than in the younger ones.

The joint space extends throughout the length of theanterior slices but is replaced by fibrous tissue pos-⿳亠丷厂犬 teriorly.

Fig. 5(a-c) shows a slice and the corresponding $x$ ray and microscopic appearances of a section of Slice 1, Case 5. $\overline{\bar{A}}$

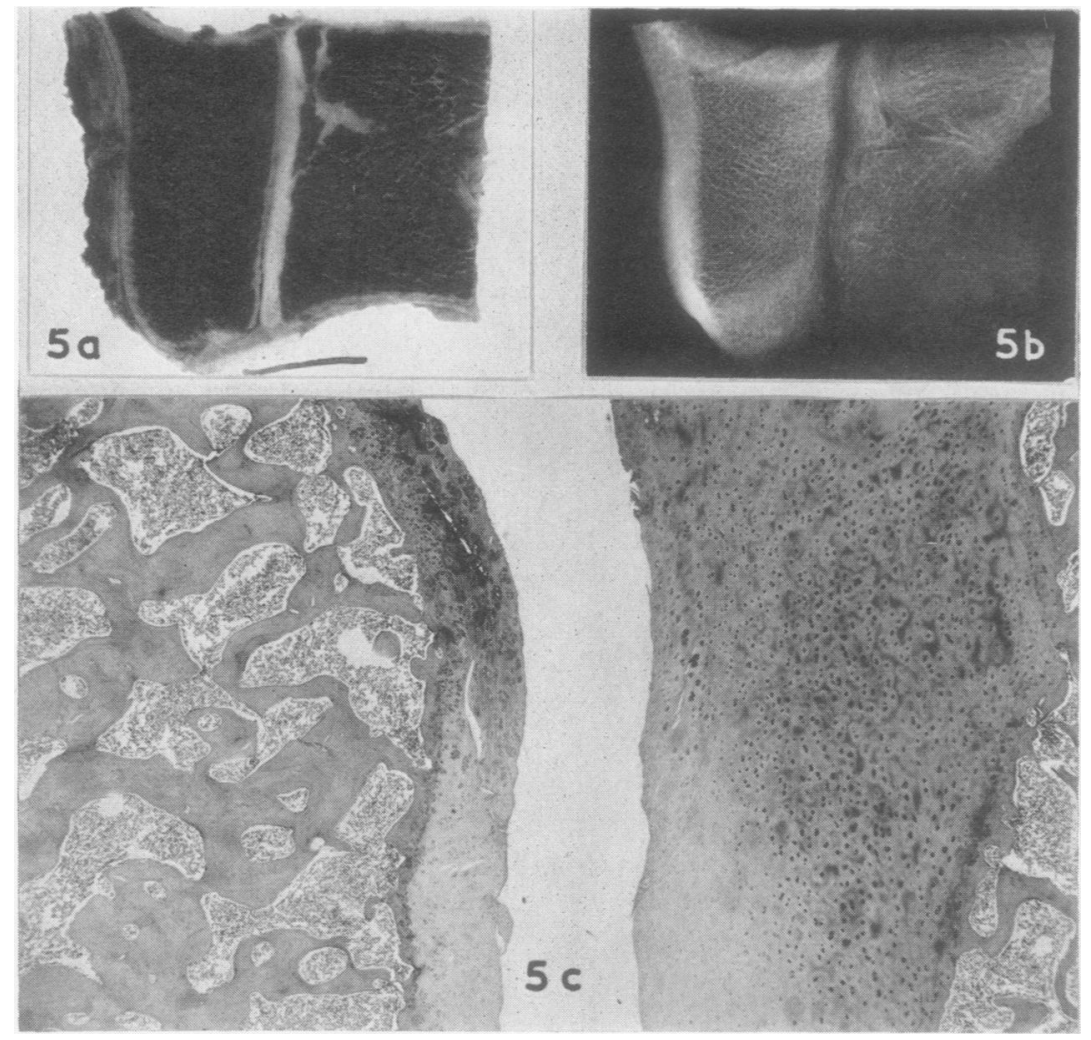

Fig. 5(a).-Case 5 (17 yrs). Slice 1 (anterior) left sacro-iliac joint.

Fig. 5(b).-Radiograph of Slice 1.

Fig. 5(c).-Lower end of left sacro-iliac joint. Sacral cartilage on right and iliac on left. $\times 14$.

Macroscopic and Microscopic Appearances of Coronal Sections of Sacro-iliac Joints from Two Patients with Still's Disease

(1) Case 7, 9 years and 7 months old at the time of death, had suffered from severe nodular, seropositive Still's disease with erosions since the age of 4 . She had bilateral hip disease, and was immobilized for at least 6 months. She died from encephalitis after whooping cough. An antero-posterior radio-0 graph of the pelvis (post mortem) shows doubtfup irregularity at the margins of the right anterion joint space (Fig. 6a), but the left side is not suffi $\frac{\overrightarrow{\mathbb{Q}}}{\mathbb{2}}$ ciently well seen for comment. The pelvic $x$ rays taken when the patient was living showed "probable 
change" in the right sacro-iliac joint but none in the left. The quality of this $x$ ray is poor. Macroscopically the most anterior slice of the left joint follows the normal appearance of the other specimens, but the right anterior slice shows almost no space, the sacral and iliac cartilages being apparently fused. Similarly, the second left slice shows a narrow space bordered by broad sacral and narrow iliac cartilage, whereas the corresponding right slice shows little space, and only a narrow single band of cartilage in the lower one-third, intermittently broken, the upper two-thirds of the joint area being filled in the normal way with fibrous tissue.

The third and most posterior left slice shows only a very small length of narrow space, but the cartilage is still broad. The most posterior right slice shows neither joint space nor cartilage.

Microscopically, the left joint cartilage is normal in appearance except at its upper end, where the iliac cartilage is predominantly fibrous and fuses with the sacral cartilage. The right joint shows more cellular cartilage structure and nearly complete continuity of cartilage between the two bones, with only small intermittent spaces. There is no sign of any inflammatory tissue in the joint and the underlying bone is normal. Fig. 6b-o (overleaf) shows slices and corresponding $x$ rays of the right and left joints and microscopic details of joints.

(2) Case 8, 20 years old at the time of death (from peritonitis following pyosalpinx), had also suffered from severe sero-positive nodular Still's disease with erosions since the age of 12 years; she had bilateral hip involvement, but had not been subjected to prolonged periods of immobilization. The sacroiliac joints were removed at autopsy. An anteroposterior radiograph (Fig. 7a, overleaf) shows some narrowing of posterior joint spaces, and marginal sclerosis; though border-line in appearance, it was finally placed in the normal category. The left sacro-iliac joint was cut into five slices.

Slice 1 shows a band of sacral cartilage which is narrower than those of all the previously-described younger patients. The joint space is visible as a thin line throughout the length of the section. The iliac cartilage is only just visible, and there are patches of vascular tissue invading the cartilage and adjacent bone throughout the length of the joint. The radiograph of this slice shows erosive change in the margin of the iliac bone. Microscopically, this section reveals pathological changes which are mostly concentrated in the iliac half of the joint. There is erosion of cartilage and bone with pannus formation and invasion of the bony spaces with granulation tissue. The sacral side of the joint is scarcely affected, being only slightly eroded at the top and bottom limits.

Slice 2 shows the same ragged appearance macroscopically on the iliac side of the joint. A narrow space is visible at the lower one-fifth, but the joint appears to be fused in its upper four-fifths. The sacral cartilage is also very thin, but is still present throughout the length of the joint area. The radiograph of this slice shows erosions at the margin of the iliac bone. Microscopically this section showed joint space in the lower one-fifth, with intermittent spaces in the upper four-fifths. Vascular granulation tissue with dead bone fragments fills the areas of cartilage erosion on the iliac side. Where the space ends there are fibro-cartilaginous bridges containing some inflammatory tissue, and at the upper end of the joint the cartilage is continuous from iliac to sacral side.

Slice 3, taken more posteriorly, shows narrow joint space in the lower one-third, the upper twothirds being occupied mainly by fibrous tissue (Fig. $7 f$, overleaf). The radiograph of the slice shows little evidence of erosion. Microscopically the joint space in the lower portion is bordered by iliac cartilage which is invaded in its deep aspect by vascular rheumatoid granulation tissue containing giant cells and occasionally, in the upper portions, necrotic fragments of dead bone where it breaks through the cartilage to the surface. The fibrofatty part of the joint above this is filled with normal but vascular connective tissue, until at the upper end of the section further areas of iliac erosion and pannus forming the margin of the joint cavity are seen again.

Slice 4 (the most posterior) shows no joint space, and only a small band of sacral cartilage at the lower end, with a thin lining of iliac cartilage. The junction between the two bones appears to be filled with fibrous tissue, with fibro-fatty tissue at the upper extremity. The radiograph shows no obvious erosions in the posterior part of the joint. Microscopically, there is destruction of the iliac surface by granuloma at the lower end, where space is present, and the sacral cartilage is also affected. Further up, in the region of the fibrocartilaginous band where there is no joint space, there is no sign of disease. Similar changes were seen in the right sacro-iliac joint. This case illustrates the pathology associated with rheumatoid arthritis in both sacro-iliac joints in a female aged 20 years. Fig. $7 b-l$ (overleaf) shows slices, $x$ rays of slices, and the microscopy of the joint. 
Fig. 6(a).-Case 7 (9 yrs, Still's disease). Antero-posterior $x$ ray of pelvis (post mortem).
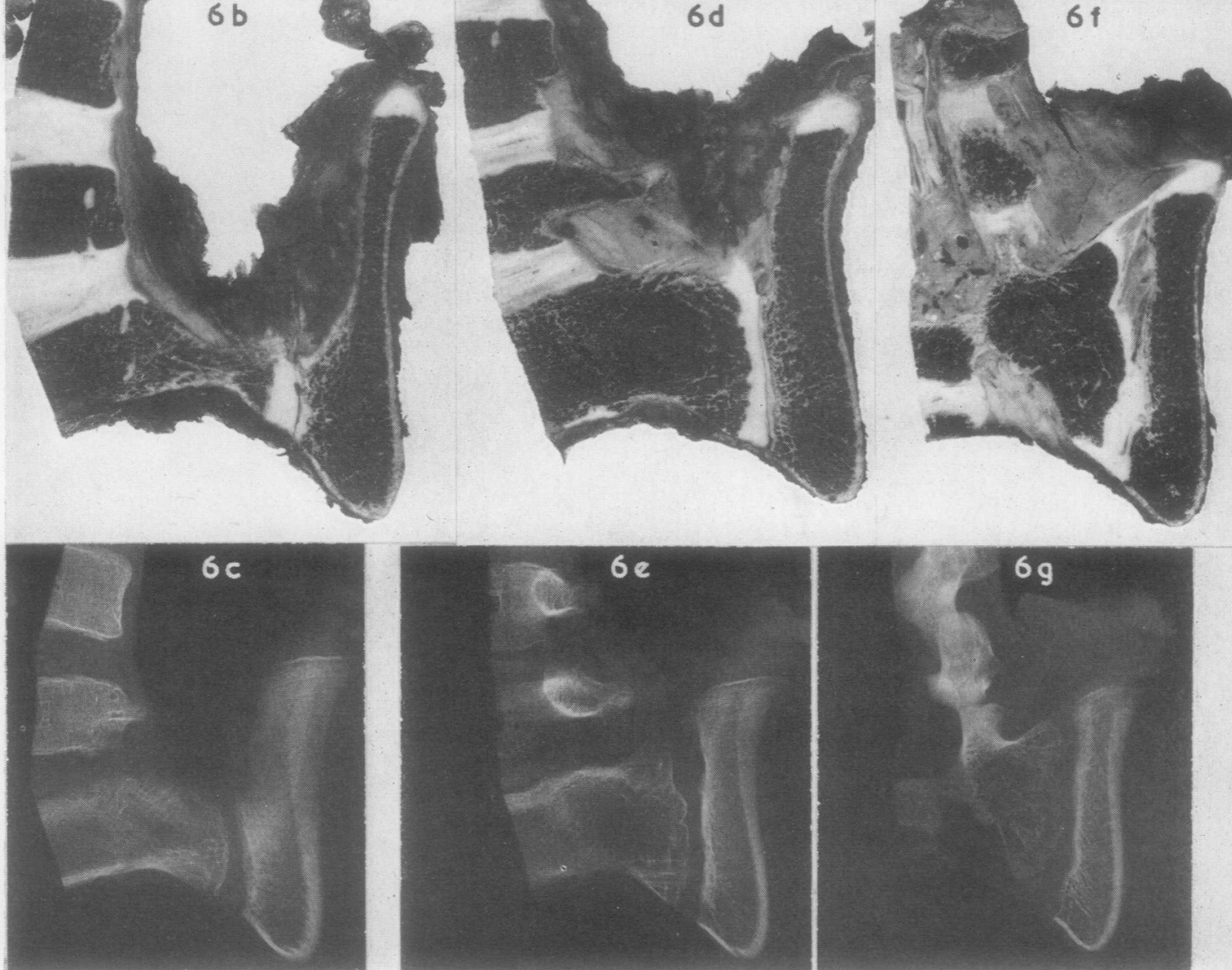

Fig. $6(f)$.-Slice 3 of left sacro-iliac joint.

Fig. 6(b).-Slice 1 (anterior) of left sacro-iliac Fig. 6(d).-Slice 2 of left sacro-iliac joint. joint.

Fig. 6(c).-Radiograph of Slice 1.

Fig. 6(e).-Radiograph of Slice 2.

Fig. 6(g).-Radiograph of Slice 3.

Fig. 6(h).-Mid-zone of left sacro-iliac joint at level of Slice 1. Sacral cartilage on left and iliac on right. $\times 12$. 

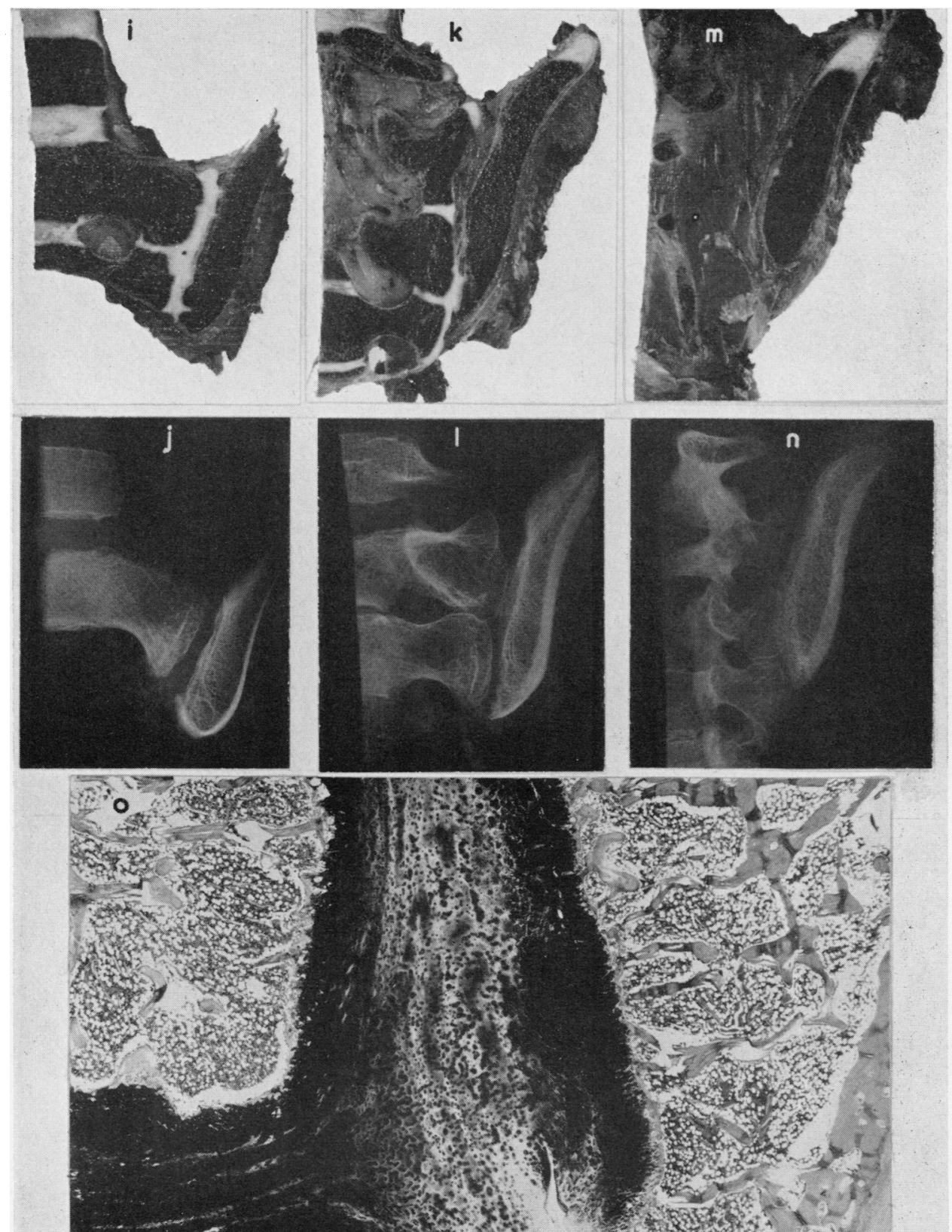

Fig. 6(i).-Slice 1 (anterior) of right sacro- Fig. 6(k).-Slice 2 of right sacro-iliac joint. iliac joint.

Fig. 6(j).-Radiograph of Slice 1 .

Fig. 6(l).-Radiograph of Slice 2.

Fig. $6(m)$.-Slice 3 (posterior) of sacro-iliac joint.

Fig. 6(n).-Radiograph of Slice 3.

Fig. 6(o).-Mid-zone of right sacro-iliac joint at level of Slice $2 . \times 12$. 


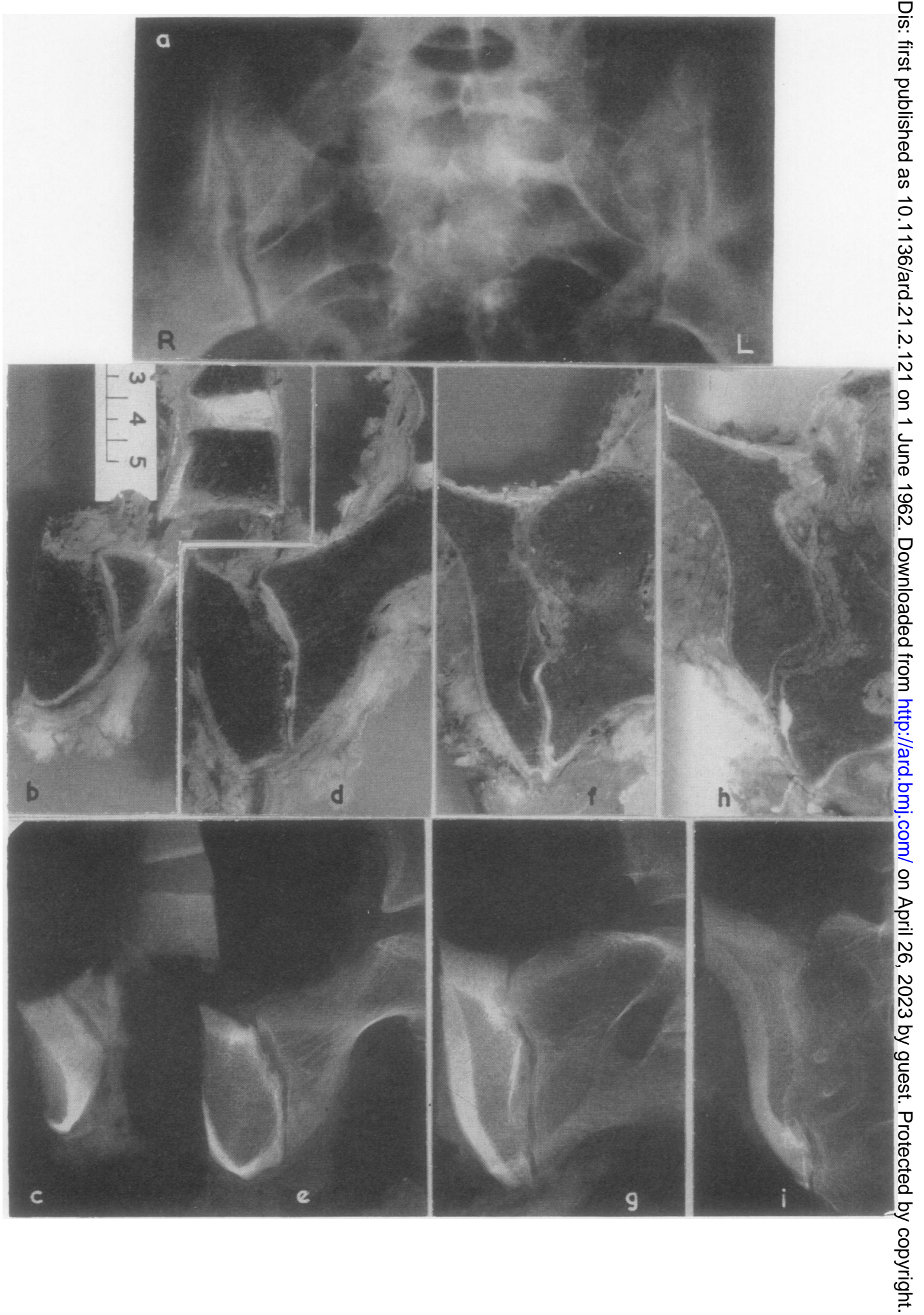


Fig. 7(a).-Case 8 (20 yrs, Still's disease). Antero-posterior $x$ ray of sacro-iliac joints.

Fig. 7(b).-Slice 1 (anterior) of left sacro-iliac joint. Sacral cartilage on right and thin eroded iliac cartilage on left.

Fig. 7(c).-Radiograph of Slice 1, showing erosions of ilium (on left).
Fig. $7(d)$.-Slice 2 of left sacroiliac joint, showing more extensive erosion of iliac bone.

Fig. 7(e).-Radiograph of Slice 2 , showing deeper bony erosions.
Fig. $7(f)$.- Slice 3 of left sacroiliac joint, showing less marked erosions at this level.

Fig. 7(g).-Radiograph of Slice Fig. 7(i).--Radiograph of Slice 4.

Fig. $7(g)$. - Radiograph of Slice

Fig. $7(h)$.-Slice 4 of left sacroiliac joint.

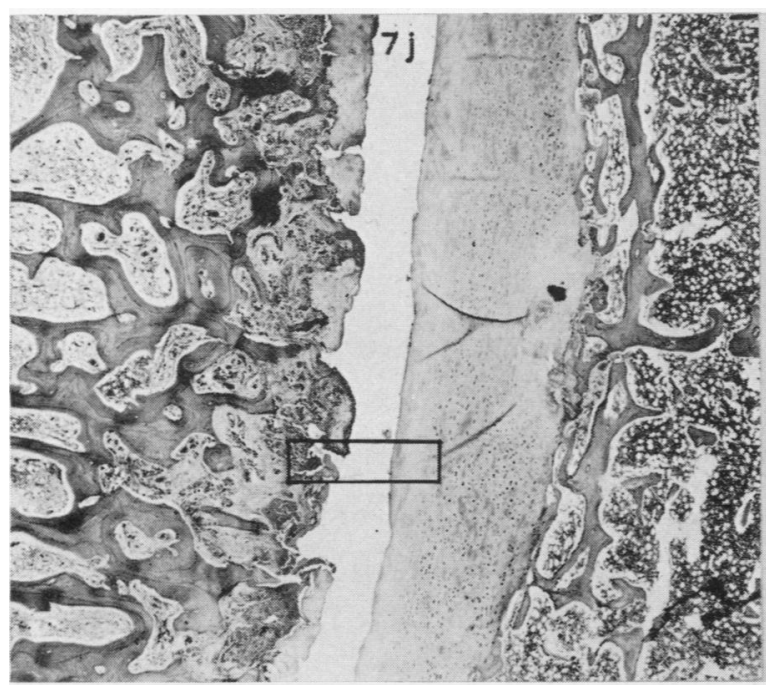

Fig. $7(j)$.-Mid-zone of left sacro-iliac joint at level of Slice 1. Sacral cartilage on right and eroded iliac cartilage on left. $\times 12$.

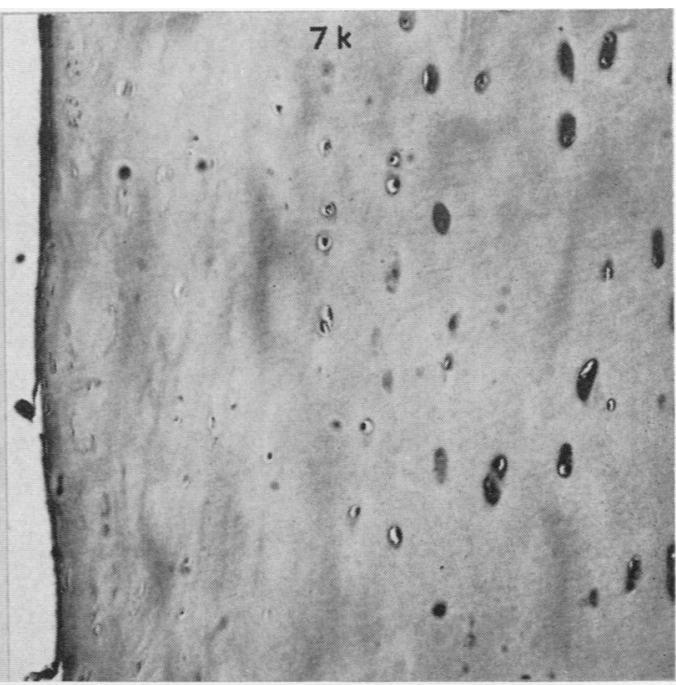

Fig. $7(k)$.-Sacral cartilage and joint margin, unaffected by rheumatoid change. $\times 130$.

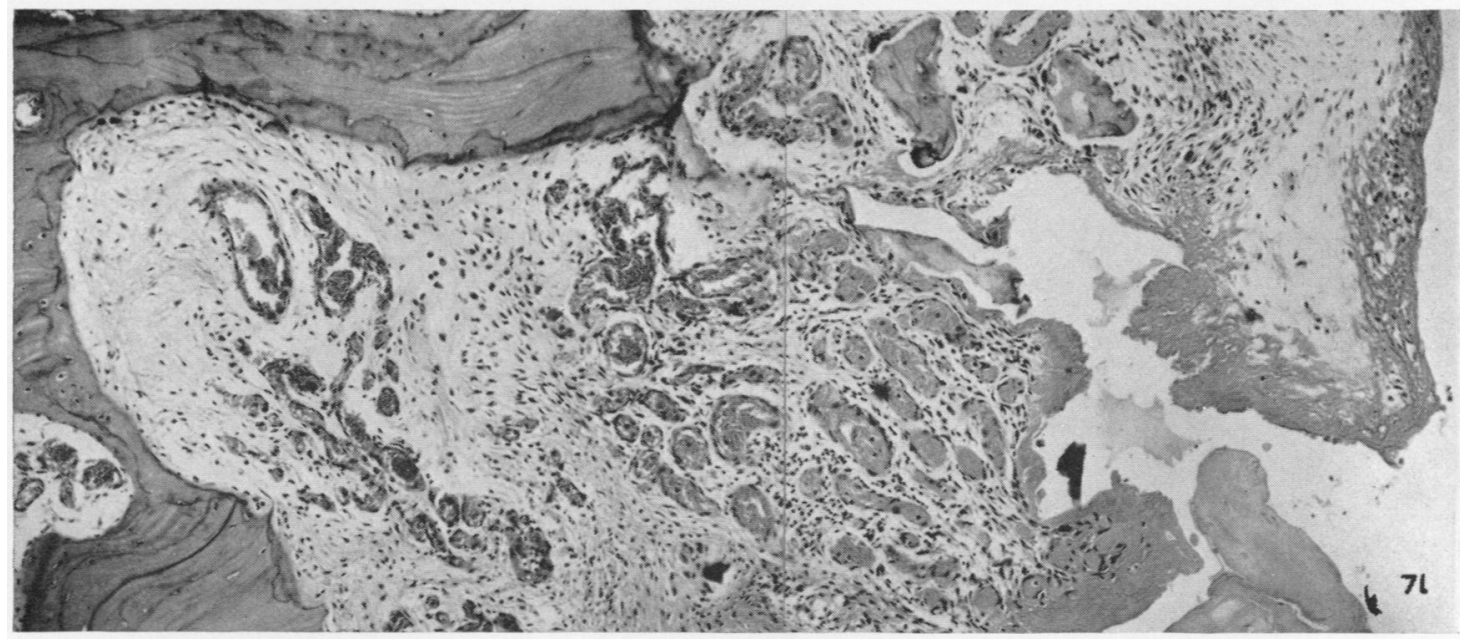

Fig. $7(l)$.-Section of iliac cartilage, showing gross disruption by invading granuloma. $\times 130$.

\section{Discussion}

In the youngest normal joints the free cartilage margins are mostly intact, although there is slight irregularity and splitting of the iliac surface which becomes more pronounced with increasing age.
Case 7 (Still's disease) showed an abnormal right sacro-iliac joint with a more normal left joint. The right side showed loss of space due to fusion of cartilage, but there was no sign of inflammation, and it is thought that this may be the result of 
prolonged immobilization and/or severe hip involvement.

Case 8 (Still's disease) showed chronic inflammatory change in both sacro-iliac joints similar to that seen in peripheral rheumatoid arthritis, and it is of interest that the involvement is concentrated on the iliac side of the joint, where the cartilage is always much thinner and appears to have normal "splits" at right angles to the joint margin, a feature which may facilitate the invasion by granuloma.

The literature on the histology of sacro-iliac joints is scanty, and Sashin (1930) appears to be the only writer concerned with histological changes in various age groups. However, in his "under 30" group, one patient was 1 year old and one was 15 , and the rest were all over 16 years; the two juveniles are not described individually. Schunke (1938) and Macdonald and Hunt (1952) described specimens from foetal, new-born, and one 9-month-old baby, but no other juveniles are included. There has been much controversy on the nature of sacro-iliac joints, some maintaining that they are amphiarthrodial and others that they are di-arthrodial. Sashin (1930) ascribed this confusion to the early onset of pathological changes in these joints; they are di-arthrodial, he says, often only until early adult life, after which they are amphi-arthrodial or completely ankylosed. Descriptions of his "under30" group are similar to ours, except that he does not refer to the "splitting" of the iliac cartilage seen in all but the youngest of our specimens. Collins (1949) suggests that, as sacro-iliac joints tend to lose their hyaline structure at an early age and to become replaced by fibro-cartilage from which fibrous bands extend across the joint space, non-inflammatory fibrous ankylosis of the joint may be a physiological event. There have been no previous reports on the histology of affected sacro-iliac joints in rheumatoid arthritis, hence no correlation with $x$ rays of these joints.

\section{Summary}

Six pairs of sacro-iliac joints from young patients without joint disease are described anatomically, and related to their radiological appearance. These are contrasted with sacro-iliac joints from two patients with severe Still's disease, the younger of whom (9 years) showed abnormality mainly of the right sacro-iliac joint with absence of joint space due to fusion of cartilage. This change may be due to immobilization. The older specimen (20 years shows rheumatoid arthritis in both sacro-iliac joints? which is not apparent in the pelvic $x$ ray.

\section{REFERENCES}

Carter, M. E. (1962). Ann. rheum. Dis., 21, 105.

Collins, D. H. (1949). " "The Pathology of Articular an Spinal Diseases", p. 316. Arnold, London.

Macdonald, G. R., and Hunt, T. E. (1952). Canad? med. Ass. J., 66, 157.

Sashin, D. (1930). J. Bone Jt Surg., 12, 891.

Schunke, G. B. (1938). Anat. Rec., 72, 313.

Altérations anatomiques dans les articulations sacro을 iliaques normales pendant l'enfance et comparaison avec' des altérations dans la maladie de Still

\section{RÉSUMÉ}

Six paires d'articulations sacro-iliaques de jeuneso patients ne souffrant d'aucune maladie articulaire sone décrites du point de vue anatomique par rapport à l'aspect radiologique. Ensuite on procède à des como paraisons avec des articulations sacro-iliaques de deue jeunes gens atteints d'une grave maladie de Still. Le plus jeune des deux ( 9 ans) accusait surtout une anomalio de l'articulation sacro-iliaque droite, avec absence $d Q$ l'espace articulaire, due à la fusion du cartilage. Cette altération aurait pu être due à l'immobilisation. L'autre' cas, plus vieux ( 20 ans) manifestait une atteinte rhumatis male des deux articulations sacro-iliaques, peu apparente à la radiographie du bassin.

Cambios anatómicos en articulaciones sacro-iliaca normales durante la infancia y comparación con los cambios en la enfermedad de Still

SUMARIO

Seis pares de articulaciones sacro-iliacas de pacientes jóvenes sin enfermedad articular son descritas anatómicao mente y relacionadas con su aspecto radiológico. Esta son comparadas con las articulaciones sacro-iliacas d dos pacientes con severa enfermedad de Still, el más. joven de los cuales ( 9 años) mostraba anormalida principalmente de la articulación sacro-iliaca derechaos con ausencia de espacio articular, debida a la fusión dẹt cartílago. Este cambio puede deberse a la inmovilización El caso más viejo (20 años), mostraba artritis reumatoide en ambas articulaciones sacro-iliacas, que no erg్ demostrable en la radiografía de la pelvis. 